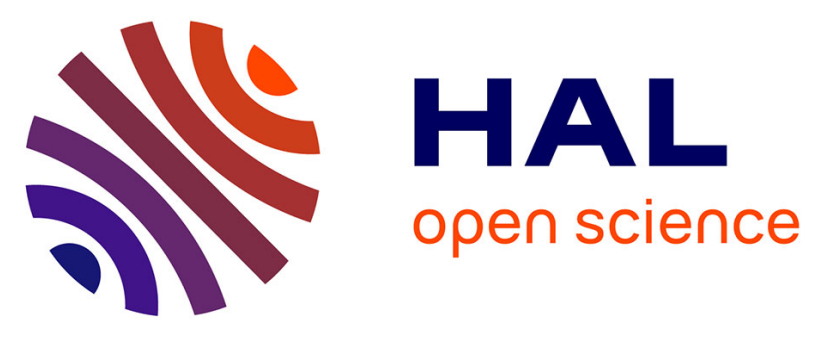

\title{
Severe hematologic complications after lung transplantation in patients with telomerase complex mutations
}

Raphael Borie, Caroline Kannengiesser, Sandrine Hirschi, Jérôme Le Pavec, Hervé Mal, Emmanuel Bergot, Stéphane Jouneau, Jean-Marc Naccache, Patrick Revy, David Boutboul, et al.

\section{To cite this version:}

Raphael Borie, Caroline Kannengiesser, Sandrine Hirschi, Jérôme Le Pavec, Hervé Mal, et al.. Severe hematologic complications after lung transplantation in patients with telomerase complex mutations. The Journal of Heart and Lung Transplantation, 2015, 34 (4), pp.538-546. 10.1016/j.healun.2014.11.010 . hal-01146848

\section{HAL Id: hal-01146848 \\ https://hal-univ-rennes1.archives-ouvertes.fr/hal-01146848}

Submitted on 19 May 2015

HAL is a multi-disciplinary open access archive for the deposit and dissemination of scientific research documents, whether they are published or not. The documents may come from teaching and research institutions in France or abroad, or from public or private research centers.
L'archive ouverte pluridisciplinaire HAL, est destinée au dépôt et à la diffusion de documents scientifiques de niveau recherche, publiés ou non, émanant des établissements d'enseignement et de recherche français ou étrangers, des laboratoires publics ou privés. 


\section{Severe hematological complications after lung transplantation in patients with telomerase complex mutations}

Raphael Borie ${ }^{1}$, Caroline Kannengiesser ${ }^{2}$, Sandrine Hirschi ${ }^{3 \S}$, Jérôme Le Pavec ${ }^{4 \S}$, Hervé Mal ${ }^{5}$, Emmanuel Bergot ${ }^{6}$, Stéphane Jouneau ${ }^{7}$, Jean-Marc Naccache ${ }^{8}$, Patrick Revy ${ }^{9}$, David Boutboul 10, Régis Peffault de la Tour ${ }^{11}$, Lidwine Wemeau-Stervinou ${ }^{12}$, Francois Philit ${ }^{13}$, Jean-François Cordier ${ }^{13}$, Gabriel Thabut ${ }^{4}$, Bruno Crestani ${ }^{{ }^{*}}$, Vincent Cottin ${ }^{13^{*}}$, and the Groupe d'Etudes et de Recherche sur les maladies « orphelines » pulmonaires (GERM«O»P)

Corresponding author :

Bruno Crestani, Service de pneumologie A, hôpital Bichat, 46 rue Henri Huchard, 75877 Paris CEDEX 18

Tel +33140256800 Fax + 33140258818

Mail bruno.crestani@bch.aphp.fr

1 APHP, Hôpital Bichat, Service de Pneumologie A, Centre de compétence des maladies pulmonaires rares, Paris, France; INSERM, Unité 1152, Paris, France; Université Paris Diderot

2 Laboratoire de Génétique, APHP, Hopital Bichat, Paris, France; Université Paris Diderot, Paris, France

3 Service de Pneumologie, Centre de compétence des maladies pulmonaires rares, Hôpitaux Universitaires de Strasbourg, Strasbourg, France

4 Service de chirurgie thoracique et de transplantation pulmonaire, Centre Chirurgical Marie Lannelongue, Le Plessis-Robinson

5 Service de Pneumologie B, APHP, Hôpital Bichat, Paris, France

6 Service de Pneumologie, CHU de Caen, Caen, France, 
7 Service de Pneumologie, Centre de compétence des maladies pulmonaires rares, hôpital Pontchaillou, Rennes,

France, IRSET UMR 1085, université de Rennes 1, 35043 Rennes cedex, France

8 Service de Pneumologie, Centre de compétence des maladies pulmonaires rares, Hôpital Tenon, Paris, France

9 INSERM UMR 1163, Laboratory of Genome Dynamics in the Immune System, Paris Descartes - Sorbonne Paris

Cité University, Imagine Institute, Paris, France

10 Service d'Immunopathologie clinique, APHP, hôpital St Louis, Paris, France

11 Service d’Hématologie greffe, centre de référence maladie rare aplasie médullaire, APHP, hôpital St Louis, Paris, France

12 Service de Pneumologie, Centre de compétence des maladies pulmonaires rares, CHRU de Lille, Lille, France

13 Service de Pneumologie, Centre national de référence des maladies pulmonaires rares, Hôpital Louis Pradel,

Université Claude Bernard Lyon 1, Lyon, France

* These authors contributed equally to this work.

$\S$ These authors contributed equally to this work.

\section{Acknowledgment}

The authors are particularly indebted to the following: Elodie Lainey, Thierry Leblanc, Gaelle Dauriat, Olivier Brugière, Anne-Cécile Métivier, Bernard Grandchamp, Peter Dorfmuller, Clement Picard, Martine Raynaud-Gobert, Thierry Leblanc, Lionel Galicier, Huguette Lioté, Benoit Wallaert, Alienor Xhaar, Jacques Cadranel, Marc Stern, Caroline Boissel-Suberbielle, Sandra de Miranda, Philippe Delaval, Charlotte Fitte, Nadia Nathan, Serge Amsellem, Annick Clement, Antoine Roux, Diane Bouvry, Hilario Nunes, Dominique Valeyre, Julie Traclet, Chahéra Khouatra, Jean-François Mornex, Nicolas Pottier, Claire Danel.

Short title: Lung transplantation with telomere syndrome 


\section{Abstract}

Background: Mutations in the telomerase complex (TERT and TR) are associated with pulmonary fibrosis and frequent hematological manifestations. The aim of this study was to characterize the prognosis of lung transplantation in patients with TERT or TR mutations.

Methods: Patients with documented TERT or TR mutations who received a lung transplantation in 2007-2013 in France were identified exhaustively through the lung transplantation network, one expert genetic laboratory, and the clinical research network on rare pulmonary diseases.

Results: Nine patients ( 7 men) with $\operatorname{TERT}(\mathrm{n}=6)$ or $\operatorname{TR}(\mathrm{n}=3)$ mutations received a single $(\mathrm{n}=8)$ or a double $(n=1)$ lung transplantation for pulmonary fibrosis. Median age was 50 years [range, 3561] at diagnosis and 52 years [37-62] at the time of lung transplantation. Seven patients had thrombocytopenia before lung transplantation. Six patients developed myelodysplasia and/or bone marrow failure after lung transplantation, directly contributing to death in 4 cases. Anemia and neutropenia were observed in 9 and 3 patients, respectively. The median survival after lung transplantation was 214 days [59-1709].

Conclusion: Patients with mutations of the telomerase complex are at high risk of severe hematological complications after lung transplantation namely bone marrow failure. Specific recommendations should be developed for appropriate guidance regarding the hematological risk assessment before transplantation and the management of post-transplantation immunosuppressive regimen.

Word count 3650

\section{Abstract word count 217}


Keywords Idiopathic Pulmonary Fibrosis; genetics; familial; thrombocytopenia; myelodysplastic syndromes 


\section{INTRODUCTION}

Idiopathic pulmonary fibrosis (IPF) is associated with a median survival time of about 3 years [1]. Lung transplantation has been shown to improve survival in selected patients [2]. The prevalence of IPF is estimated at $1 / 2500$ to $1 / 7000$, and $2 \%$ to $20 \%$ of IPF patients have at least one first-degree family member with a fibrotic lung disease [3-4]. Genetic studies in familial forms of IPF led to the discovery of mutations within TERT (encoding the telomerase reverse transcriptase) and TR (encoding the telomerase RNA component), which are both required for normal telomerase activity [5]. Heterozygous mutations within TERT or TR are detected in 15\% to $20 \%$ of the cases of familial forms of pulmonary fibrosis (PF), whereas they are very rarely detected in sporadic IPF (<3\%) [5-7]. In addition to PF, mutations in the telomerase complex are associated with mucocutaneous abnormalities such as dyskeratosis congenita (abnormal skin pigmentation, nail dystrophy, oral leukoplakia), and possibly severe complications including liver cirrhosis and bone marrow failure. As the phenotype may be heterogeneous and the same TERT mutations can be associated with different phenotypes of lung disease even in the same family [8], individual risk prediction is challenging.

We recently evidenced a TERT mutation in a patient with PF, who developed bone marrow failure following lung transplantation, triggering the present study. The largest published experience only reports 8 patients with telomerase mutations and lung transplantation from 3 different countries [9]. Therefore we reviewed the results of lung transplantation in all the patients with PF associated with TERT or TR mutations in France, in order to determine whether these patients were at risk of hematological complications. 


\section{METHODS}

\section{PATIENTS}

In this retrospective, observational, non-interventional study, all ten French lung transplant centers were contacted in order to identify patients with TERT or TR mutations referred for lung transplantation during the $2009-2013$ period, as the laboratory of genetics began to perform these sequencing in 2009. In addition, cases were cross-identified through the only genetic laboratory in France that centrally assesses for telomerase mutations, and by the Groupe d'Etudes et de Recherche sur les Maladies "Orphelines" Pulmonaires (GERM"O"P), a collaborative group dedicated to research on rare (so-called "orphan") pulmonary diseases.

All the patients with PF with known mutations of TERT or TR who received a lung transplantation during the study period in France were included. The clinical charts of the patients were reviewed and data were collected on a standardized and anonymous collection form. Chest CT scans, biopsies and explants were systematically classified based on a multidisciplinary team discussion in each of the 4 expert centers involved in this study and classified according to the 2011 official ATS/ERS/JRS/ALAT statement for IPF [2, 10] and the revised classification of idiopathic interstitial pneumonia [11]. Haematogical manifestations including myelodysplastic syndromes were classified according to the 2008 WHO classification [12].

All patients or relatives gave signed consent for genetic analysis. The Institutional Review Board of the French learned society for respiratory medicine -Société de Pneumologie de Langue Française- approved this study (CEPRO 2012-016). 
Survival and characteristics at the time of lung transplantation were compared to a control group of patients with PF, extracted from the database of Agence de Biomedicine that collects data from all organ transplants in France, for the same period (2009-2013) and same centers. During the 2009-2013 period, 9 patients with known TERT or TR mutations included in this series, and 196 patients with non-familial PF and unknown mutational status received lung transplantation. Physicians in charge of lung transplantation in corresponding centres were queried for occurrence of myelodysplastic syndrome following transplant.

\section{TERT AND TR SEQUENCING}

Exons, intron-exon junctions and promoters of $T E R T$ and $T R$ were sequenced by bi-directional sequencing (primers sequences available on request) and compared to the reference sequences for TERT : NM_198253.2 and TERC:NR_001566.1.

\section{TELOMERE LENGTH}

The telomere length was evaluated by terminal restriction fragment assay. DNA from blood cells was extracted, digested by the Hinf1 and Rsa1 nucleases (which do not digest telomere DNA sequences), submitted to a Southern blot using a specific telomere probe, and compared to those found in healthy age-matched controls [13].

\section{STATISTICAL ANALYSIS}

Data for continuous variables are expressed as median (range) and were compared by the Mann-Whitney $U$ test. Categorical variables were expressed as counts and proportions and compared by the Fisher's exact test. Survival was studied and compared with a Kaplan-Meier analysis. Categorical variables are expressed as number and percentage and were compared by 
the Fisher's exact test. All tests were two-sided, with $p<0.05$ indicating statistical significance.

All analyses used the Graph-Pad Prism 5 software (La Jolla, Ca, USA).

\section{RESULTS}

\section{Clinical characteristics at the diagnosis of pulmonary fibrosis}

Nine patients with TERT or TR mutations received lung transplantation in France from January 2009 to October 2013. The main clinical characteristics of the patients at diagnosis are shown in Table 1. Interstitial lung disease was diagnosed as IPF in 7 patients, pneumoconiosis in 1 patient, and chronic hypersensitivity pneumonitis in 1 patient. Six patients had some degree of exposure to inhaled contaminants (Table 1). Six patients presented with extra-pulmonary manifestations suggestive of telomere syndrome: 5 with hematological abnormalities, 1 with isolated unexplained liver enzymes elevation, and 3 with mucocutaneous abnormalities: nail dystrophy $(n=2)$, hypopigmented macules $(n=1)$, premature hair graying $(n=1)$, and mucosal leukoplakia $(n=1)$.

Median age at PF diagnosis was 50 years [range, 35-61]. Patients had pulmonary symptoms for 6 months [1-59] prior to the diagnosis of lung fibrosis. Dyspnea was the most frequent symptom $(n=8)$, although one patient was asymptomatic at the time of diagnosis. Pulmonary function tests (PFT) results showed a reduced vital capacity (VC) (63\% [40-88] of the predicted value) with reduced diffusion capacity for carbon monoxide (DLCO) (38\% [16-77] of predicted).

The CT scans were reviewed and classified as definite usual interstitial pneumonia (UIP) pattern in 5 cases, possible UIP pattern in 3 cases, and consistent with chronic hypersensitivity pneumonitis in 1 patient. A video-assisted surgical lung biopsy was performed before lung 
transplantation in 5 patients; 3 samples were classified as a definite UIP pattern, 1 as a probable UIP pattern and 1 as unclassifiable fibrosis. Lung explants were classified pathologically as UIP pattern in 2 cases, probable UIP pattern in 5 cases (absence of fibroblast foci), not UIP pattern in 2 cases. The diagnosis was pneumoconiosis in one case; due to the presence of granuloma, the diagnosis of chronic hypersensitivity pneumonitis was suggested in one case.

The median follow-up between the PF diagnosis and lung transplantation was 24.6 [4.5-72.2] months. Before transplantation, all patients received corticosteroids, 5 patients had received immunosuppressants (azathioprine, $n=3$; cyclophosphamide, $n=2$ ), and 2 patients received pirfenidone (Table 2). None of the treatment was associated with any objective pulmonary improvement assessed either by CT scan or an increase in VC or DLCO by $10 \%$ of the predicted value or greater. At the last visit before transplantation, VC and DLCO were 42\% [75-22] and $22 \%[15-33]$ of predicted, respectively.

\section{Genetic analysis}

Telomerase mutations were identified before $(n=5)$, or after lung transplantation $(n=4)($ Table 3), including post-mortem in two cases. Indication of TERT and TR sequencing were a familial history of lung fibrosis $(n=4)$, hematological abnormalities $(n=2)$, or both $(n=3)$. Two patients presented with both personal hematological abnormalities and a familial history of lung fibrosis and thrombocytopenia. Telomere lengths measurement was near or below $5 \mathrm{~kb}$, and considered as abnormally short compared to age-matched controls in all 5 tested cases [13].

\section{Hematological abnormalities before transplantation}


At the time of PF diagnosis and prior to any therapy, 4 patients had thrombocytopenia with a median platelet count of $59 \mathrm{G} / \mathrm{L}$ [50-66], and 1 patient had mild anemia (113 g/L) (Figure 1). During the pre-transplant period, 3 additional patients developed thrombocytopenia $(53,108$ and $135 \mathrm{G} / \mathrm{L}$, respectively), including 1 patient who received corticosteroids and pirfenidone alone, and 2 patients who were treated with azathioprine. Proband \#5 received azathioprine before lung transplantation and did not develop cytopenia. Six patients had macrocytosis (mean corpuscular volume, $101 \mathrm{fL}$ [101-103]) before lung transplantation, at the time of the lung fibrosis diagnosis in two patients, and during follow-up in four additional patients. Three of them had received azathioprine, but macrocytosis persisted after azathioprine withdrawal. During follow-up, only 1 patient developed macrocytic non-regenerative anemia (117 g/L). Neither neutropenia, nor monocytosis greater than $1 \mathrm{G} / \mathrm{L}$ developed in any patients. Two patients received cyclophosphamide before lung transplantation, and did not have hematological complications. Bone marrow cytology was available in 4 patients before lung transplantation (Table 4) considered as normal in 1 patient, and consistent with the diagnosis of refractory cytopenia with unilineage dysplasia in the 3 others. Karyotype was normal in all 4 tested cases.

\section{General evolution in the post transplantation period}

Eight patients received a single-lung transplantation and 1 patient received a double-lung transplantation. Five patients underwent high emergency lung transplantation. Table 2 shows the post-transplantation therapies received. None of them received alemtuzumab or antithymocyte globulin. The median survival from the time of transplantation was 214 days (Figure 
2). At the end of follow-up, 3/9 patients were alive, 310, 747 and 1709 days after transplantation. The causes of deaths are indicated in Table 4. Two patients with persistent pancytopenia received multiple platelets and blood transfusions, granulocyte-colony stimulating factor (G-CSF) and erythropoietin injections. Hematopoietic stem cell transplantation was not considered and palliative care was started. Finally, death occurred and was attributed to refractory pancytopenia. Two patients died from sepsis, related to Staphylococcus haemolyticus and Enterobacter cloacae, respectively; neutrophil counts were within the normal range, whereas platelet counts were reduced at $25 \mathrm{G} / \mathrm{L}$ and $9 \mathrm{G} / \mathrm{L}$. In those patients, deaths likely occurred because of the lung transplantation complications and myelodysplastic syndromes. One patient died from pulmonary embolism unrelated to myelodysplastic syndrome. The cause of death remained unknown for one patient. Two of the 3 living patients have myelodysplastic syndromes.

Lung function tests were available after lung transplantation in 5 patients, all with single-lung transplantation. Forced expiratory volume in 1 second (FEV1) was 48\% [38-64] and 40\% [28-68] of the predicted values, 3 and 6 months after transplantation, respectively. The best FEV1 available was $50 \%$ [38-74] of the predicted values. In the 3 patients alive, the last follow-up visit showed a FEV1 of $44 \%, 53 \%$, and $59 \%$ of the predicted values, respectively. During follow-up, three patients developed acute transplant rejection requiring increased doses of corticosteroids. The diagnosis of rejection was made after clinical suspicion and not on systematic biopsies. One patient developed a second episode of acute rejection. The severity of acute rejection was classified with transbronchial biopsies as A1B0 for 2 patients, and clinically 
highly suspected for one patient but not confirmed by histology because of thrombocytopenia. Based on PFT, none of them developed bronchiolitis obliterans syndrome.

\section{Comparison with a control group}

Patients from the control group with pulmonary fibrosis and unknown mutational status $(\mathrm{N}=196)$ were more frequently women $(25 \%, \mathrm{P}=0.03)$. Their median age was $55.4+/-3.0$ years ( $P=0.12$ vs mutated patients). The diagnosis of myelodysplastic syndrome was given in 2 patients from the control group.

The median survival of the control group was 1301 days and was not statistically different from the mutated group $(p=0.85)$. Lung transplantation was less frequently a high emergency procedure in controls than in mutated patients ( $25 \%$ vs $55 \%, \mathrm{P}=0.04)$. In the control group, high emergency procedure was associated with poorer survival (167 days for high emergency procedure vs 1437 days without high emergency procedure, $\mathrm{P}=0.004)$. After excluding patients transplanted with high emergency procedures, survival was not different between the control and mutated groups.

\section{Post-transplantation infections and hematological abnormalities}

Due to the frequent use of extracorporeal circulation in the perioperative period, the nadir of thrombocytopenia was defined starting at day 7 post-transplantation. Thrombocytopenia worsened after lung transplantation in 5/7 patients who had thrombocytopenia prior to the transplantation, reaching a platelets count of $25 \mathrm{G} / \mathrm{L}$ [8-28]. The 4 other patients did not present with thrombocytopenia, including 1 patient previously treated with azathioprine (Figure 1). Two 
patients who received azathioprine and one who received induction therapy with basiliximab, had worsening of thrombocytopenia (Figure 1). Two of the 3 patients treated with cyclosporine also had thrombocytopenia. Three patients received everolimus for a short duration without worsening of cytopenia. The thiopurine methyltransferase activity, which when low is associated with azathioprine toxicity [14], was available for 2 patients with severe pancytopenia and was normal.

All the patients developed anemia (Figure 1). Three patients had neutropenia with neutrophils counts of $0.1,0.8$ and $0.8 \mathrm{G} / \mathrm{L}$, respectively. Two of them also had a thrombotic microangiopathy at that time. Bone marrow cytology was consistent with a myelodysplastic syndrome in 6 patients (Table 4): refractory anemia with excess blasts type $1(n=1)$, refractory cytopenia with multilineage dysplasia $(n=4)$, refractory cytopenia with unilineage dysplasia $(n=1)$.

Severe infections occurred in 6 patients (Table 4). One patient had pulmonary infection with Pneumocystis jiroveci while co-trimoxazole was withdrawn due to cytopenia. Isolated CMV viremia developed in 3 patients, whose treatment by ganciclovir was limited by cytopenia.

Except thrombotic microangiopathy, which occurred in 2 cases, no patient presented acute renal failure. These patients died while they were still in need for dialysis. Only 1 patient had mildly elevated liver enzymes (below twice the upper limit of normal).

\section{DISCUSSION}

This is the largest report on outcomes of lung transplantation in a comprehensive series of patients with $T E R T$ or $T R$ mutations. The main finding of the present study is that hematological 
complications following lung transplantation were more frequent in this patient population than in a control group of lung transplant recepients for PF, with possible sepsis related to bone marrow failure, therefore warranting close attention of clinicians both for the pre-transplant evaluation, and in the post-transplant follow-up period.

Patients with familial PF are usually younger than 65 years, and may therefore be considered as adequate candidates for lung transplantation $[8,15]$. Our series underscores that TERT and TR mutations may be revealed not only by familial history of PF but also by extra-pulmonary signs of telomere syndrome such as bone marrow failure or liver disease [16]. Moreover hematological complications, mainly thrombocytopenia, may be absent at the time of diagnosis and develop during follow-up particularly in subjects receiving cytotoxic drugs.

Our data indicate that cytopenia, and particularly thrombocytopenia, is a common complication in telomerase mutation carriers exposed to cytotoxic drugs. Compared to matched family members without mutation, patients with TERT mutations have lower platelets count although generally within normal limits [17]. The co-occurrence of bone marrow failure and PF in the same individual or family is highly predictive of telomerase mutation [18]. In a previous series [9], all patients with telomerase mutations and PF had thrombocytopenia after lung transplantation, with a majority of them requiring platelet transfusion. Nearly all our patients had anemia after lung transplantation, and neutropenia was frequent with cytotoxic drugs, however thrombocytopenia was the most prominent manifestation. Thrombocytopenia should be considered highly suggestive of telomerase mutations in this setting.

The median survival of 214 days following transplantation in this series was very low, compared to that reported by the International Society for Heart and Lung Transplantation (ISHLT) in 
transplant recipients with PF, who have a median survival of 4.3 years [19]. However, mortality could be increased due to the high rate (55\%) of high emergency lung transplantation and to the frequent use of extracorporeal circulation [20]. The survival time in our series also compares unfavourably with the study of Silhan et al., in which 7 of their 8 patients were still alive after a median follow-up of 1.9 years [9]. However, the small number of patients in the latter series (e.g. only 8 patients identified among transplant recipients from the USA, Australia, and Sweden), may suggest that results by Silhan et al., be biased by selection and recall bias, with possible underdiagnosis of PF related to telomerase mutations and/or underestimation of the severity of complications (early deaths are frequently underrepresented in retrospective series [21]). The present series may better and more realistically reflect the severity of complications in transplant recipients carrying telomerase mutations. In addition, differences in immunosuppressive regimen between the present series and that of Silhan et al., may have contributed to differences in outcome. Indeed, while most subjects in the Silhan study received a two-drug immunosuppressive regimen, all the patients from our cohort received a third additional immunosuppressive drug. Of note, data from the literature further suggest that azathioprine may be more toxic than mycophenolate mofetil in this setting [22], an hypothesis that needs to be evaluated. Azathioprine, mycophenolate mofetil and cyclophosphamide likely contributed to the haematological complications. In our study, all patients received drugs with established hematological toxicity co-trimoxazole $(N=9)$, ganciclovir $(N=4)$, or voriconazole $(N=4)$ but none received linezolid.

In view of the poor results of transplantation, some patients from the current series might be considered contra-indicated for lung transplantation, especially those with myelodysplastic 
syndrome. In the future, genetic testing might be considered in the pre lung transplantation work-up.

Two patients presented thrombotic microangiopathy, with low serum level of disintegrin and metalloproteinase with thrombospondin motifs (ADAMTS13), and died. One patient from the current series presented low level of ADAMTS13 ( $<40 \%$ of the normal value) without thrombotic microangiopathy. Thrombotic microangiopathy has been previously reported after lung transplantation [23], and we speculate that ADAMTS13 synthesis might be reduced in patients with mutations even in the absence of cirrhosis.

Identifying telomerase mutation may be challenging in patients evaluated for lung transplantation since myelodysplastic syndromes may only appear after cytotoxic drugs exposure, and the clinical / biological presentation may vary. The high rate of cytopenia after exposure to cytotoxic drugs in mutation carriers illustrates the abnormal repair capacities after external injury in these patients, and the phenotype heterogeneity according to age and environmental exposure. This is consistent with the fact that mutation carriers are more prone to develop liver cirrhosis associated to hepatitis C virus infection or alcohol exposure [24]. Similarly, environmental risk factors including tobacco or inhaled contaminants are found with a high frequency (96\%) in patients with PF and a TERT mutation [8]. Indeed some patients with TERT or TERC mutations, without specific trigger could remain asymptomatic [8]. However TERT or $T R$ mutations in the general population are very rare $(<1 / 10000)$.

All patients from this cohort fulfilled clinical telomere syndrome criteria. However some mutations have not been reported previously [9][25]. Three mutations were already published in the telomerase database and considered deleterious [26]. None of the novel mutations were 
found in database of controls (Exome variant server; 1000 Genome project), and Polyphen (polymorphism phenotyping) predicted all of them to be probably damaging. Telomere lengths assessed in 5 patients were shorter than that of age-matched controls in every case [13]. Experience of organ transplantation in telomerase mutations carriers is very limited. In addition to series of lung transplantation (the series by Silhan et al. [9][25], and the present one), one report of liver transplantation has been published in a 63 year-old man with hepatocellular carcinoma, PF and TERT mutation, who experienced worsening of PF and died four months after the liver transplantation [27]. A patient with dyskeratosis congenita associated with a Telomeric Repeat-binding factor TRF1-Interacting Nuclear Factor 2 (TINF2) mutation, an additional mutation associated with the telomere syndrome [28], underwent lung transplantation for PF at the age of 13 , ten years after receiving hematopoietic stem cell transplantation for severe aplastic anemia; he experienced neutropenia due to mycophenolate mofetil, which was withdrawn, and was reported to be doing well 21 months after lung transplantation with tacrolimus treatment.

From a hematological point of view, patients with telomerase dysfunction are at high risk of pulmonary complications after hematopoietic stem cell transplantation [29]. Therefore a procedure with reduced immunosuppression is currently proposed for patients with dyskeratosis congenita [29-31]. Some reports suggest that mycophenolate mofetil and azathioprine may be safely removed from the drug regimen following lung transplantation [28, 32]. Whether mycophenolate mofetil might be better tolerated than azathioprine in this setting warrants further study. 
One limitation of the present study is its retrospective design. However, the use of different sources (the single genetic laboratory with expertise in telomerase genes in France; all transplantation centers in France; and over 200 physicians participating to a network of clinical research on rare pulmonary diseases) ensured exhaustive identification in France of all cases of PF diagnosed with a mutation within the telomerase complex. It is conceivable that some cases with telomerase mutations may have been missed in the control group, as it can be hypothesized in the 2 patients with a diagnosis of myelodysplastic syndrome. Indeed, the TERT and TERC mutational status could not be analysed retrospectively in the control group. However TERT mutations were previously found in no more than 1-3\% of sporadic IPF cases [34-35]. The diagnosis of myelodysplastic syndrome in the control group was retrieved by querying physicians, possibly underestimating its frequency. A prospective study with mutational status known before lung transplantation would be the only way to obtain definitive conclusions. Exhaustive collection of hematological data and of infectious events was comprehensively and reliably obtained through electronic patients charts. We therefore consider that this series is representative of the reality of lung transplantation in this particular population of patients. In conclusion, severe hematological complications are observed in patients with PF and mutations of the telomerase complex who receive a lung transplantation. We suggest thatlung transplantation should be discouraged in patients with myelodysplasia, and should be considered on a case-by-case basis in remaining cases. Specific recommendations should be developed for appropriate guidance regarding the hematological risk assessment before transplantation and the management of post-transplantation immunosuppressive regimen. 
The authors declare neither funding nor conflict of interest relevant to this work. 


\section{Bibliography}

1. Nathan SD, Shlobin OA, Weir N, et al. Long-term course and prognosis of idiopathic pulmonary fibrosis in the new millennium. Chest 2011; 140:221-229.

2. Raghu G, Collard HR, Egan JJ, et al. An official ATS/ERS/JRS/ALAT statement: idiopathic pulmonary fibrosis: evidence-based guidelines for diagnosis and management. Am J Respir Crit Care Med 2011; 183:788-824.

3. van Moorsel CH, van Oosterhout MF, Barlo NP, et al. Surfactant protein C mutations are the basis of a significant portion of adult familial pulmonary fibrosis in a dutch cohort. Am J Respir Crit Care Med 2010; 182:1419-1425.

4. Hodgson U, Laitinen T, and Tukiainen P. Nationwide prevalence of sporadic and familial idiopathic pulmonary fibrosis: evidence of founder effect among multiplex families in Finland. Thorax 2002; 57:338-342.

5. Tsakiri KD, Cronkhite JT, Kuan PJ, et al. Adult-onset pulmonary fibrosis caused by mutations in telomerase. Proc Natl Acad Sci U S A 2007; 104:7552-7557.

6. Armanios MY, Chen JJ, Cogan JD, et al. Telomerase mutations in families with idiopathic pulmonary fibrosis. N Engl J Med 2007; 356:1317-1326.

7. Borie R, Crestani B, Dieude P, et al. The MUC5B variant is associated with idiopathic pulmonary fibrosis but not with systemic sclerosis interstitial lung disease in the European Caucasian population. PLoS One 2013; 8:e70621.

8. Diaz de Leon A, Cronkhite JT, Katzenstein AL, et al. Telomere lengths, pulmonary fibrosis and telomerase (TERT) mutations. PLoS One 2010; 5:e10680.

9. Silhan LL, Shah PD, Chambers DC, et al. Lung transplantation in telomerase mutation carriers with pulmonary fibrosis. Eur Respir J 2014; 44:178-187.

10. Cottin V, Crestani B, Valeyre D, et al. Diagnosis and management of idiopathic pulmonary fibrosis: French practical guidelines. Eur Respir Rev 2014; 23:193-214.

11. Travis WD, Costabel U, Hansell DM, et al. An official American Thoracic Society/European Respiratory Society statement: Update of the international multidisciplinary classification of the idiopathic interstitial pneumonias. Am J Respir Crit Care Med 2013; 188:733-748.

12. Swerdlow SH, Campo E, Harris NL, et al., WHO Classification of Tumours of Haematopoietic and Lymphoid Tissues, Fourth Edition. WHO Classification of Tumours. 2008. 439.

13. Touzot F, Gaillard L, Vasquez N, et al. Heterogeneous telomere defects in patients with severe forms of dyskeratosis congenita. J Allergy Clin Immunol 2012; 129:473-482, 482 e471-473.

14. Maddocks JL, Lennard L, Amess J, Amos R, and Thomas RM. Azathioprine and severe bone marrow depression. Lancet 1986; 1:156.

15. Kotloff RM and Thabut G. Lung transplantation. Am J Respir Crit Care Med 2011; 184:159-171.

16. Armanios M and Blackburn EH. The telomere syndromes. Nat Rev Genet 2012; 13:693704.

17. Diaz de Leon A, Cronkhite JT, Yilmaz C, et al. Subclinical lung disease, macrocytosis, and premature graying in kindreds with telomerase (TERT) mutations. Chest 2011; 140:753-763. 
18. Parry EM, Alder JK, Qi X, Chen JJ, and Armanios M. Syndrome complex of bone marrow failure and pulmonary fibrosis predicts germline defects in telomerase. Blood 2011; 117:5607-5611.

19. Christie JD, Edwards LB, Kucheryavaya AY, et al. The Registry of the International Society for Heart and Lung Transplantation: twenty-seventh official adult lung and heartlung transplant report--2010. J Heart Lung Transplant 2010; 29:1104-1118.

20. Boussaud V, Mal H, Trinquart L, et al. One-year experience with high-emergency lung transplantation in France. Transplantation 2012; 93:1058-1063.

21. Schulz KF and Grimes DA. Case-control studies: research in reverse. Lancet 2002; 359:431-434.

22. Risdall RJ, McKenna RW, Nesbit ME, et al. Virus-associated hemophagocytic syndrome: a benign histiocytic proliferation distinct from malignant histiocytosis. Cancer 1979; 44:993-1002.

23. Mal H, Veyradier A, Brugiere O, et al. Thrombotic microangiopathy with acquired deficiency in ADAMTS 13 activity in lung transplant recipients. Transplantation 2006; 81:1628-1632.

24. Hartmann D, Srivastava U, Thaler M, et al. Telomerase gene mutations are associated with cirrhosis formation. Hepatology 2011; 53:1608-1617.

25. Silhan LL, Shah PD, Chambers DC, et al. Lung transplantation in telomerase mutation carriers with pulmonary fibrosis. Eur Respir J 2014;

26. http://telomerase.asu.edu/diseases.html\#tert.

27. Valenti L, Dongiovanni P, Maggioni M, et al. Liver transplantation for hepatocellular carcinoma in a patient with a novel telomerase mutation and steatosis. J Hepatol 2013; 58:399-401.

28. Giri N, Lee R, Faro A, et al. Lung transplantation for pulmonary fibrosis in dyskeratosis congenita: Case Report and systematic literature review. BMC Blood Disord 2011; 11:3.

29. Langston AA, Sanders JE, Deeg HJ, et al. Allogeneic marrow transplantation for aplastic anaemia associated with dyskeratosis congenita. Br J Haematol 1996; 92:758-765.

30. Dokal I. Dyskeratosis congenita in all its forms. Br J Haematol 2000; 110:768-779.

31. Nishio N, Takahashi Y, Ohashi H, et al. Reduced-intensity conditioning for alternative donor hematopoietic stem cell transplantation in patients with dyskeratosis congenita. Pediatr Transplant 2011; 15:161-166.

32. Miyazaki T, Tagawa T, Yamasaki N, et al. Two case reports of successful withdrawal of mycofenolate mofetil after living donor lobar lung transplantation. Transplant Proc 2013; 45:356-359.

33. Raghu G, Anstrom KJ, King TE, Jr., Lasky JA, and Martinez FJ. Prednisone, azathioprine, and N-acetylcysteine for pulmonary fibrosis. N Engl J Med 2012; 366:1968-1977.

34. Cronkhite JT, Xing C, Raghu G, et al. Telomere shortening in familial and sporadic pulmonary fibrosis. Am J Respir Crit Care Med 2008; 178:729-737.

35. Alder JK, Chen JJ, Lancaster L, et al. Short telomeres are a risk factor for idiopathic pulmonary fibrosis. Proc Natl Acad Sci U S A 2008; 105:13051-13056. 
Table 1 Characteristics at the time of pulmonary fibrosis diagnosis

\begin{tabular}{lc}
\multicolumn{1}{c}{ Characteristics } & $\begin{array}{c}\text { Patients } \\
\mathrm{N}=9\end{array}$ \\
\hline Male (\%) & $7(77)$ \\
\hline Age at diagnosis, years & $50[35-61]$ \\
Smoker ever/active & $6(66) / 0(0)$ \\
\hline $\begin{array}{l}\text { Occupational or environmental exposure* } \\
\text { telomeropathy } \\
\bullet \quad \text { Hematological }\end{array}$ & $6(66)$ \\
\hline - Platelets count <150G/L & $6(66)$ \\
\hline - Anemia & $5(55)$ \\
\hline - Macrocytosis & $4(44)$ \\
\hline
\end{tabular}

Data are presented as median [range] or n (\%). Anemia was defined by WHO criteria. Macrocytosis was defined by a mean corpuscular volume (MCV) $>100 \mathrm{fL}$.

* Two patients worked as farmers, two worked as construction workers, one as carpenter and one as polisher 
Table 2 Pre and post transplantation therapy and duration of treatment

\begin{tabular}{|c|c|c|}
\hline Drugs & Pre-transplantation & Post-transplantation \\
\hline Corticosteroids & $\begin{array}{c}9(100) / \\
625 \text { days [128-2017] }\end{array}$ & $\begin{array}{c}9(100) / \\
214 \text { days [59-1709] }\end{array}$ \\
\hline Azathioprine & $\begin{array}{c}3(33) / \\
792 \text { days [118-1219] }\end{array}$ & $\begin{array}{c}2(22) / \\
80-219 \text { days }\end{array}$ \\
\hline N-Acetylcysteine & $\begin{array}{c}2(22) / \\
594-625 \text { days }\end{array}$ & $0(0)$ \\
\hline Pirfenidone & $\begin{array}{c}2(22) / \\
59-790 \text { days }\end{array}$ & $0(0)$ \\
\hline Cyclophophamide & $\begin{array}{c}2(22) / \\
106-224 \text { days }\end{array}$ & $0(0)$ \\
\hline Proton Pump Inhibitor & $\begin{array}{c}4(44) / \\
\text { na }\end{array}$ & $\begin{array}{c}7(77) / \\
\text { na }\end{array}$ \\
\hline Mycophenolate mofetil & $0(0)$ & $\begin{array}{c}9(100) / \\
79 \text { days [13-905] }\end{array}$ \\
\hline Tacrolimus & $0(0)$ & $\begin{array}{c}9(100) / \\
111 \text { days [41-967] }\end{array}$ \\
\hline Cyclosporin & $0(0)$ & $\begin{array}{c}3(33) / \\
111 \text { days [13-112] }\end{array}$ \\
\hline Everolimus & $0(0)$ & $\begin{array}{c}3(33) / \\
25 \text { days [14-43] }\end{array}$ \\
\hline Basiliximab (induction) & $0(0)$ & $\begin{array}{l}1(11) / \\
4 \text { days }\end{array}$ \\
\hline
\end{tabular}

Data are presented as $\mathrm{n}(\%)$.

Duration of treatment is expressed as median [range] or minimum-maximum for $n<3$. na, not available. 
Table 3 Mutations in $h T E R T, h T R$ and telomere lengths in the 9 probands

\begin{tabular}{|c|c|c|c|c|c|c|}
\hline $\begin{array}{l}\text { Proband } \\
\text { No. }\end{array}$ & $\begin{array}{l}\text { Age at } \\
\text { presentation } \\
\text { (years) }\end{array}$ & Gender & Gene & Mutation & $\begin{array}{l}\text { Previously } \\
\text { described } \\
\text { mutation }\end{array}$ & $\begin{array}{l}\text { Telomere } \\
\text { lengths } \\
(\mathrm{kb})\end{array}$ \\
\hline 1 & 38 & $M$ & hTERT & $\begin{array}{l}\text { c. } 2911 \text { C>T, } \\
\text { p.Arg971Cys }\end{array}$ & No & ND \\
\hline 2 & 39 & $M$ & hTERT & $\begin{array}{l}\text { c. } 2639 \mathrm{C}>\mathrm{T}, \\
\text { p.Ala880Val }\end{array}$ & No & 5.26 \\
\hline 3 & 57 & $M$ & hTERT & $\begin{array}{l}\text { c. } 1864 C>T, \\
\text { p.Arg622Cys }\end{array}$ & No & ND \\
\hline 4 & 61 & $M$ & hTERT & $\begin{array}{l}\text { c.1630T>C, } \\
\text { p.Phe544Leu }\end{array}$ & No & 4.32 \\
\hline 5 & 35 & $\mathrm{~F}$ & hTERT & $\begin{array}{l}\text { c. } 2935 C>T \text {, } \\
\text { p.Arg } 971 \text { Cys }\end{array}$ & [1] & 5.29 \\
\hline 6 & 58 & $M$ & hTERT & $\begin{array}{l}\text { c.1710G >C, } \\
\text { p.Lys570Asn }\end{array}$ & [2] & ND \\
\hline 7 & 38 & $\mathrm{~F}$ & $h T R$ & r.110_113delGACT & {$[3-4]$} & 4.3 \\
\hline 8 & 49 & $M$ & $h T R$ & r. $1-22 C>T$ & No & 3.3 \\
\hline 9 & 55 & $M$ & $h T R$ & n.135G >C & No & ND \\
\hline
\end{tabular}

Telomeres length was assessed by Southern blot and express in kb. Telomere lengths were always considered as telomere shortening 
1. Vulliamy TJ, Walne A, Baskaradas A, et al. Mutations in the reverse transcriptase component of telomerase (TERT) in patients with bone marrow failure. Blood Cells Mol Dis 2005; 34:257-263.

2. Xin ZT, Beauchamp AD, Calado RT, et al. Functional characterization of natural telomerase mutations found in patients with hematologic disorders. Blood 2007; 109:524-532.

3. Marrone A, Sokhal P, Walne A, et al. Functional characterization of novel telomerase RNA (TERC) mutations in patients with diverse clinical and pathological presentations. Haematologica 2007; 92:1013-1020.

4. Vulliamy T, Marrone A, Dokal I, and Mason PJ. Association between aplastic anaemia and mutations in telomerase RNA. Lancet 2002; 359:21682170. 
Table 4 Pre-transplantation bone marrow cytology and evolution after lung transplantation

\begin{tabular}{|c|c|c|c|c|c|c|c|c|c|c|}
\hline $\begin{array}{l}\text { Proband } \\
\text { No. }\end{array}$ & $\begin{array}{l}\text { Age at } \\
\text { transplantation, } \\
\text { years }\end{array}$ & $\begin{array}{l}\text { Pulmonary } \\
\text { diagnosis }\end{array}$ & $\begin{array}{l}\text { ECMO/High } \\
\text { emergency } \\
\text { procedure }\end{array}$ & $\begin{array}{l}\text { Pre- } \\
\text { transplantation } \\
\text { bone marrow } \\
\text { cytology, } \\
\text { karyotype }\end{array}$ & $\begin{array}{l}\text { Post- } \\
\text { transplantation } \\
\text { bone marrow } \\
\text { cytology, } \\
\text { karyotype }\end{array}$ & $\begin{array}{l}\text { Post-transplantation } \\
\text { immunosuppression }\end{array}$ & $\begin{array}{l}\text { Post- } \\
\text { transplantation } \\
\text { infections (no.) }\end{array}$ & Status & $\begin{array}{l}\text { Follow } \\
\text {-up } \\
\text { (days) }\end{array}$ & $\begin{array}{l}\text { Cause of } \\
\text { Death }\end{array}$ \\
\hline 1 & 42 & $\mathrm{HP}$ & Yes/no & $\begin{array}{l}\text { Unilineage } \\
\text { megakaryocytic } \\
\text { dysplasia, normal }\end{array}$ & $\begin{array}{l}\text { Multilineage } \\
\text { dysplasia, 7\% } \\
\text { blasts, normal }\end{array}$ & Cs Aza MMF FK & Pneumocystosis & Alive & 310 & NA \\
\hline 2 & 40 & IPF & Yes/yes & ND & $\begin{array}{l}\text { Multilineage } \\
\text { dysplasia, } \mathrm{i}(7 \mathrm{q}) \text {, } \\
\mathrm{i}(3 \mathrm{q})\end{array}$ & Cs MMF Cyc FK & $\begin{array}{l}\text { Bacterial } \\
\text { Pneumonia ( } 3 \text { ) } \\
\text { Candida sepsis (1) } \\
\text { Bacterial sepsis } \\
(3)\end{array}$ & Dead & 197 & $\begin{array}{l}\text { Pancytop } \\
\text { enia }\end{array}$ \\
\hline 3 & 59 & IPF & Yes/yes & ND & $\begin{array}{l}\text { Multilineage } \\
\text { dysplasia, normal }\end{array}$ & Cs MMF Cус FK & $\begin{array}{l}\text { Bacterial } \\
\text { Pneumonia (3) } \\
\text { Bacterial sepsis } \\
(1)\end{array}$ & Dead & 59 & Sepsis \\
\hline 4 & 62 & Pneumoconiosis & Yes/yes & $\begin{array}{l}\text { Unilineage } \\
\text { megakaryocytic } \\
\text { dysplasia, normal }\end{array}$ & ND & Cs MMF FK & $\begin{array}{l}\text { Bacterial } \\
\text { Pneumonia (2) } \\
\text { Pyothorax (1) }\end{array}$ & Dead & 79 & $\begin{array}{l}\text { Pulmonar } \\
\text { y } \\
\text { embolis } \\
\mathrm{m}\end{array}$ \\
\hline 5 & 39 & IPF & No/no & ND & ND & Cs MMF FK & Tuberculosis & Alive & 1709 & NA \\
\hline 6 & 58 & IPF & No/no & Normal, ND & $\begin{array}{l}\text { Multilineage } \\
\text { dysplasia, normal }\end{array}$ & Cs Aza MMF FK Eve & $\begin{array}{l}\text { CMV reactivation } \\
\text { Bacterial } \\
\text { pneumonia (2) } \\
\text { Bacterial sepsis } \\
\text { (1) }\end{array}$ & Dead & 214 & Sepsis \\
\hline 7 & 45 & IPF & No/no & $\begin{array}{l}\text { Unilineage } \\
\text { megakaryocytic } \\
\text { dysplasia, normal }\end{array}$ & $\begin{array}{l}\text { Multilineage } \\
\text { dysplasia, ND }\end{array}$ & Cs MMF FK Eve Basi & $\begin{array}{l}\text { CMV reactivation } \\
\text { HHV6 encephalitis } \\
\text { Bacterial } \\
\text { Pneumonia (1) } \\
\text { Bacterial sepsis } \\
\text { (1) }\end{array}$ & Dead & 84 & $\begin{array}{l}\text { Pancytop } \\
\text { enia }\end{array}$ \\
\hline 8 & 52 & IPF & Yes/yes & ND & $\begin{array}{l}\text { Unilineage } \\
\text { megakaryocytic } \\
\text { dysplasia, ND }\end{array}$ & Cs MMF FK & $\begin{array}{l}\text { Bacterial } \\
\text { Pneumonia (3) } \\
\text { Bacterial sepsis } \\
(1)\end{array}$ & Alive & 747 & NA \\
\hline 9 & 58 & IPF & No/yes & ND & ND & Cs MMF Cyc FK Eve & CMV reactivation & Dead & 650 & Unknown \\
\hline
\end{tabular}


NA, not applicable; ND, not done,; HP, chronic hypersensitivity pneumonitis; IPF, idiopathic pulmonary fibrosis; ECMO, use of extracorporeal circulation; Cs, corticosteroids; Aza, azathioprine; MMF, mycophenolate mofetil; FK tacrolimus; Cyc, cyclosporine; Eve, everolimus; Basi, basiliximab 


\section{Figures}

Figure 1
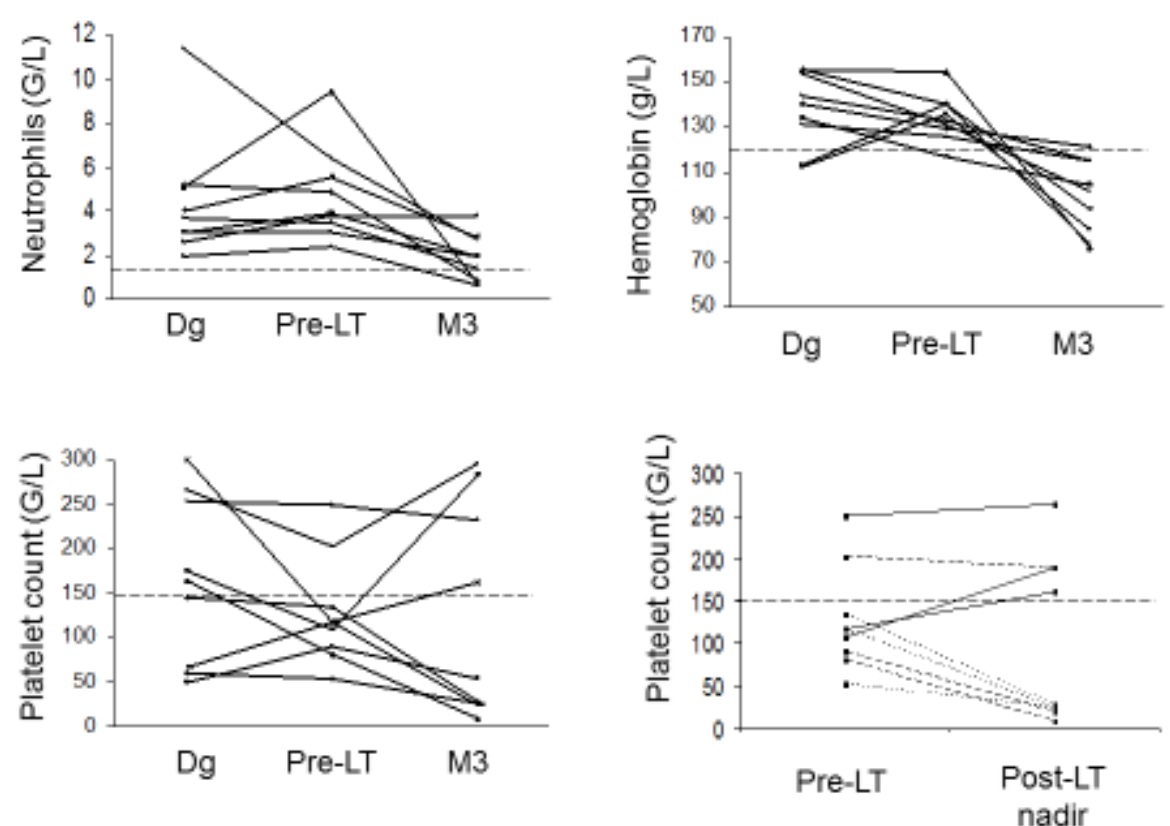

Figure 1 Evolution of platelet, neutrophil and hemoglobin counts at pulmonary fibrosis diagnosis, before lung transplantation (pre-LT) and 3 months after lung transplantation (M3) or last available data before death and post lung transplantation (postLT) nadir by post-transplantation therapy. The horizontal dashed lines highlight the normal values. Because of the frequent use of extracorporeal circulation, nadir of thrombocytopenia was defined starting at day 7 post-transplantation. Dashed lines: 
patients who received azathioprine or induction therapy $(\cdots \cdots)$, patients who received cyclosporine $(\cdot-\cdot--)$. Continuous lines: patients who did not receive azathioprine, induction therapy nor cyclosporine $(\rightarrow-)$. 
Figure 2

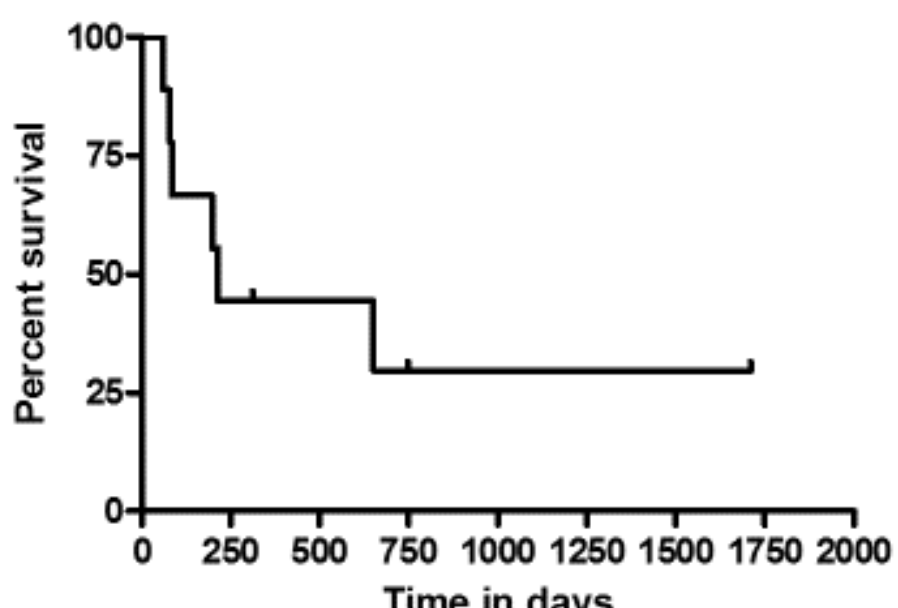

Figure 2 Kaplan-Meier estimation of overall survival after lung transplantation for 9 telomerase mutation carriers. 